\title{
A sedimentary paleomagnetic record of the upper Jaramillo transition from the Lantian Basin in China
}

\author{
Yi Wu $u^{1,2^{*}}$ (D), Tingping Ouyang ${ }^{2}$, Shifan $\mathrm{Qiu}^{3}$, Zhiguo Rao ${ }^{4}$ and Zhaoyu Zhu ${ }^{2^{*}}$
}

\begin{abstract}
The termination of the Jaramillo (normal to reverse) subchron is a key chronostratigraphic marker for dating global Pleistocene sedimentary sequences. However, the stratigraphic position of the geomagnetic polarity reversal varies greatly across the Chinese Loess Plateau (CLP), from near the bottom of paleosol unit $\$ 9$ to the middle-upper part of S10. Here, we present paleomagnetic and rock magnetic results from high-resolution sampling of the Yushan loess section of the Lantian Basin located within the southern CLP. Our combined analyses determine that the polarity reversal is located in the middle-lower part of the paleosol unit S10. This stratigraphic position is lower than most of other studies conducted throughout the CLP. We attribute the difference in the location of the reversal to a deeper lock-in depth of remanence acquisition, which may have occurred from postdepositional processes under favorable hydrothermal conditions along the southern margin of CLP. It is important to note that age determinations through magnetic stratigraphy on sedimentary sections, particularly in discontinuous and/or imperfect sequences, should be treated with caution; there are significant differences with respect to the location of the polarity reversal throughout the CLP.
\end{abstract}

Keywords: Geomagnetic reversal; Upper Jaramillo; Loess; Lantian Basin; Chinese Loess Plateau

\section{Background}

Significant progress has occurred in the construction of the chronological framework for the thick, continuous Quaternary loess sediments over throughout northern China (Heller and Liu 1982; Burbank and Li 1985; Liu 1985; Kukla 1987; Kukla et al. 1988; Liu et al. 1988; Rolph et al. 1989; Yue 1989, 1995; An et al. 1991; Zheng et al. 1992; Ding et al. 1994, 2002; Porter and An 1995; $\mathrm{Lu}$ et al. 1999; Heslop et al. 2000; Sun et al. 2006; Liu et al. 2015). Additionally, numerous studies have focused on the exact identification and/or detailed processes of geomagnetic reversals (Heller and Liu 1982; Sun et al. 1993; Zhu et al. 1994; Spassov et al. 2001, 2003; Pan et al. 2002; Liu et al. 2008; Yang et al. 2005, 2010, 2014; Jin and Liu 2010, 2011b; Wang et al. 2014; Zhao et al. 2014; Zhou et al. 2014) and excursions (Zhu et al. 1998,

\footnotetext{
*Correspondence: wuy@scsio.ac.cn; zhuzy@gig.ac.cn

'Key Laboratory of Marginal Sea Geology, South China Sea Institute of Oceanology, Chinese Academy of Sciences, Guangzhou 510301, China ${ }^{2}$ Key Laboratory of Marginal Sea Geology, Guangzhou Institute of Geochemistry, Chinese Academy of Sciences, Guangzhou 510640, China Full list of author information is available at the end of the article
}

1999; Fang et al. 1997; Pan et al. 2002; Yang et al. 2004, 2007a, 2007b, 2008; Jin et al. 2012; Sun et al. 2013) recorded in Chinese loess.

Aeolian loess of the Chinese Loess Plateau (CLP) are transported from inland deserts and desert margins in the north and northwest of China and cover an area of over 440,000 km² (e.g., Liu 1985). The entire Quaternary loess-paleosol sequence consists of 34 loess-paleosol units, which have been labeled with the $\mathrm{S}_{\mathrm{i}}-\mathrm{L}_{\mathrm{i}}$ system (e.g., Liu 1985; Kukla 1987; Ding et al. 1990, 1994, 2002; Yang and Ding 2010). There are 34 paleosol horizons (S0-S33) developed during warm interglacial periods, interbedded with 34 loess horizons (L1-L34) deposited during cold glacial periods. Meanwhile, sub-loess and sub-paleosol units have been identified and labeled within loess and paleosol units. For example, there are three sub-units of paleosols labeled as S5-1, S5-2 and S5-3 in the paleosol unit S5, two sub-units labeled as S6 and S6' (or S6 and S6-1) in S6, and two sub-units labeled as S9-1 and S9-2 in S9 (e.g., Liu 1985; Ding et al. 2002). 
The final geomagnetic reversal prior to the MatuyamBrunhes polarity reversal occurred at ca. 0.99 Ma B.P. (Shackleton et al. 1990; Cande and Kent 1995; Lisiecki and Raymo 2005) and marks the transition from Jaramillo normal subchron to Matuyama reverse chron, which is labeled as C1r.1n in the "CK95" timescale (Cande and Kent 1995). However, details of this reversal are poorly understood. Previous paleomagnetic studies on various loess sections from across the CLP indicate the termination of the Jaramillo subchron (TJ) is located between the bottom of unit S9 and the middle-upper part of S10 (Heller and Liu 1984; Liu et al. 1988; Zheng et al. 1992; Zhu et al. 1994; Guo et al. 2002; Pan et al. 2002; Yang et al. 2004; Wang et al. 2005; Liu et al. 2010). Uncertainties in age determinations of aeolian sequences in the CLP make it difficult to accurately link the deposition to other long-term geological archives, such as deep-sea and lacustrine sediments.

To better constrain the exact position of the TJ and understand its transitional process in loess, we conducted a paleomagnetic investigation with continuous sampling from the Yushan loess section within the southern CLP. The results also provide information on the specific characteristics of local depositional remanence acquisition processes in loess.

\section{Methods}

The Yushan loess section lies in the Lantian Basin at the southern margin of the CLP (Fig. 1). The Lantian Basin is located in the frontal area, which is penetrated by the East Asian summer monsoon, and has a mean annual temperature of ca. $13.1{ }^{\circ} \mathrm{C}$ and precipitation of ca. $620 \mathrm{~mm}$. The Lantian Basin is also well-known for the important Lantian Homo erectus; a fossil cranium found in the Gongwangling loess section in 1964, which was originally dated ca. 1.15 Ma (An and Ho 1989). A more recent study indicates the probable age is more likely ca. 1.63 Ma (Zhu et al. 2015). The Yushan section is located opposite the Gongwangling Paleolithic site, separated by the Bahe River (Fig. 1b). The thickness of the Yushan section is approximately $80 \mathrm{~m}$, as reported in a previous environmental magnetism investigation by $\mathrm{Wu}$ et al. (2013), where the upper section is characterized by 15 nearly horizontal paleosol units and two yellow-brown sandy loess units (namely, L9 and L15).

For this study, a continuous series of oriented block hand-samples were collected from the Yushan section between ca. 21.0 and $24.3 \mathrm{~m}$ or from the top of S9-2 to the middle of S11, yielding a total controlled thickness of about $3.3 \mathrm{~m}$. The depth of $21.0 \mathrm{~m}$ in the upper Yushan section (Fig. 1c) is defined as the zero position. In the laboratory, each hand-sample was cut into 2-cm cubic specimens. A total of 201 oriented specimens ( 29 of which are sister specimens used for comparison) and 172 powder samples were finally obtained.

Saturation isothermal remanent magnetizations (SIRM) and coercivity spectrums of 10 selected air-dried powder samples were performed and measured using a MMPM 10 pulse magnetizer and a Molspin spinner magnetometer, respectively. Temperature-dependent magnetization was conducted on three selected samples with a variable field transition balance (VFTB) under a background magnetic field of about $100 \mathrm{mT}$. Hysteresis loops were also obtained on the three samples, where the magnetic field cycled between $\pm 1.0 \mathrm{~T}$ for each sample. Data for the hysteresis loops were processed with RockMag Analyzer 1.1 designed by Leonhardt (2006). All magnetic measurements were conducted at the Key Laboratory of Western China's Environmental Systems (MOE), Lanzhou University.

The anisotropy of magnetic susceptibility (AMS) of the oriented specimens was measured using a MFK1-FA Kappabridge instrument in a magnetic field of $400 \mathrm{~A} / \mathrm{m}$ and frequency of $976 \mathrm{~Hz}$ and precision of $2 \times 10^{-8} \mathrm{SI}$. The measurements were conducted at the Guangzhou Institute of Geochemistry, Chinese Academy of Sciences (CAS). The data were processed according to Jelínek (1978).

Progressive thermal demagnetization (ThD) was also performed on 201 oriented specimens from room temperature to $585{ }^{\circ} \mathrm{C}$ (with a few up to $635{ }^{\circ} \mathrm{C}$ ). All the remanences were measured using a $2 \mathrm{G}-755 \mathrm{R}$ threeaxis cryogenic magnetometer installed in a magneticshielded room with residual fields less than $300 \mathrm{nT}$ at the South China Sea Institute of Oceanology (SCSIO), CAS. The data acquisition and analysis software were PaleoMac written by Cogné(2003) and PMGSC written by Enkin et at. (2003), respectively. The directions of remanent magnetization components for each specimen were determined by principal component analysis (Kirschvink 1980) with at least four successive data points.

Moreover, previously published anhysteretic remanent magnetization (ARM) and SIRM data of 33 samples (Wu et al. 2010) were used to evaluate any significant variations in magnetic mineralogy. The 33 samples of this study were sampled at a sampling interval of $10 \mathrm{~cm}$ (Fig. 1c). The ARM was imparted in a $100-\mathrm{mT}$ peak alternating field with a $0.05-\mathrm{mT}$ bias DC field, while the SIRM was acquired in a $1000-\mathrm{mT}$ DC field.

\section{Results}

\section{Magnetic mineralogy}

Thermomagnetic curves of the three selected samples show an obvious turning point near $580{ }^{\circ} \mathrm{C}$ (Fig. 2), indicating the main magnetization carrier is magnetite (Curie point $580{ }^{\circ} \mathrm{C}$ ). The slight decrease of magnetization when temperature rises above $580{ }^{\circ} \mathrm{C}$ might indicate the existence of hematite. Additionally, an obvious bend occurs at 


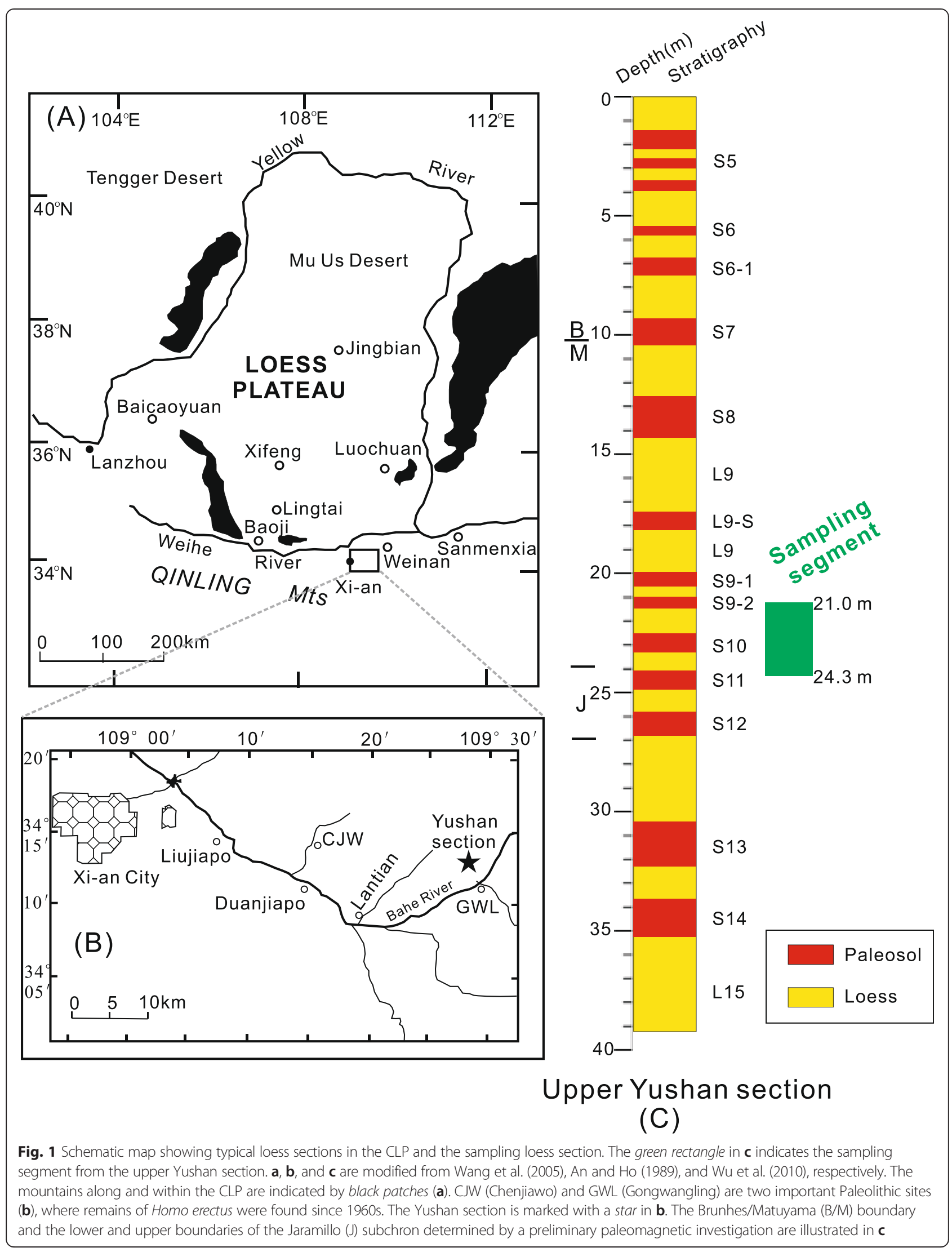




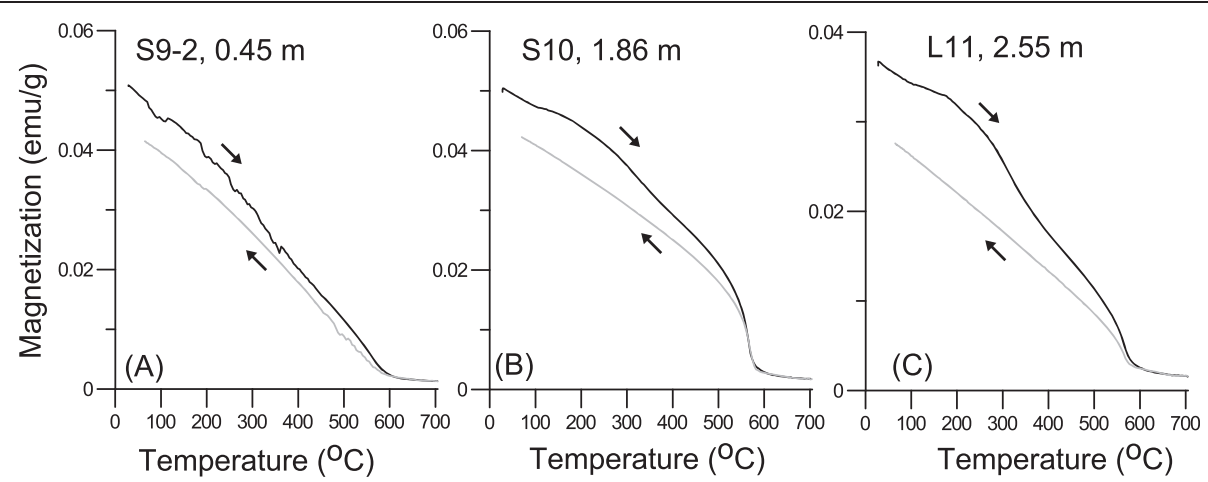

Fig. 2 Temperature-dependent magnetization curves of three selected samples. Arrows and black and gray lines represent heating and cooling runs, respectively

about $200-300{ }^{\circ} \mathrm{C}$, which is more clear in Fig. $2 \mathrm{~b}$, c, and likely reflects the conversion of thermally unstable maghemites.

In Fig. 3, the 10 selected samples show similar isothermal remanent magnetization (IRM) acquisition curves. Their rapid rises at the beginning $(<150 \mathrm{mT})$ indicate the existence of magnetically soft components. The 10 samples acquire $89.6-97.2 \%$ of SIRM (IRM at $1.5 \mathrm{~T}$ ) under $0.3 \mathrm{~T}$, implying that low-coercivity magnetic minerals (e.g., magnetite and maghemite) are the dominant carriers of the IRM. IRMs continue to increase from 0.3 to $1.5 \mathrm{~T}$, suggesting the presence of magnetically hard components, such as hematite and possibly goethite. Some abnormal fluctuations appear in the IRM acquisition curves (Fig. 3a), which may be a result from the instrument itself. Coercivity increases from 25 to ca. $53 \mathrm{mT}$ (Fig. 3b), almost contrary to the intensity of pedogenesis the samples experienced, mainly because the ultrafine pedogenic magnetic grains cannot carry remanence but contribute significantly to magnetic susceptibility.

In Fig. 4, hysteresis loops of the three representative samples exhibit no evidence of wasp-waisted characteristics, which is similar to those of loess and paleosol samples from neighboring Duanjiapo loess sections (Florindo et al. 1999), indicating no contributions from superparamagnetic grains or high-coercivity magnetic minerals (Roberts et al. 1995; Tauxe et al. 1996). The loops are basically closed when the magnetic fields rise up to ca. $300 \mathrm{mT}$ (Fig. 4), suggesting that the hysteresis behaviors are dominantly controlled by soft magnetic minerals. However, combined with the thermomagnetic discriminations and IRM curves, the magnetic components do not only include low-coercivity magnetite and maghemite but also include high-coercivity hematite and goethite. The

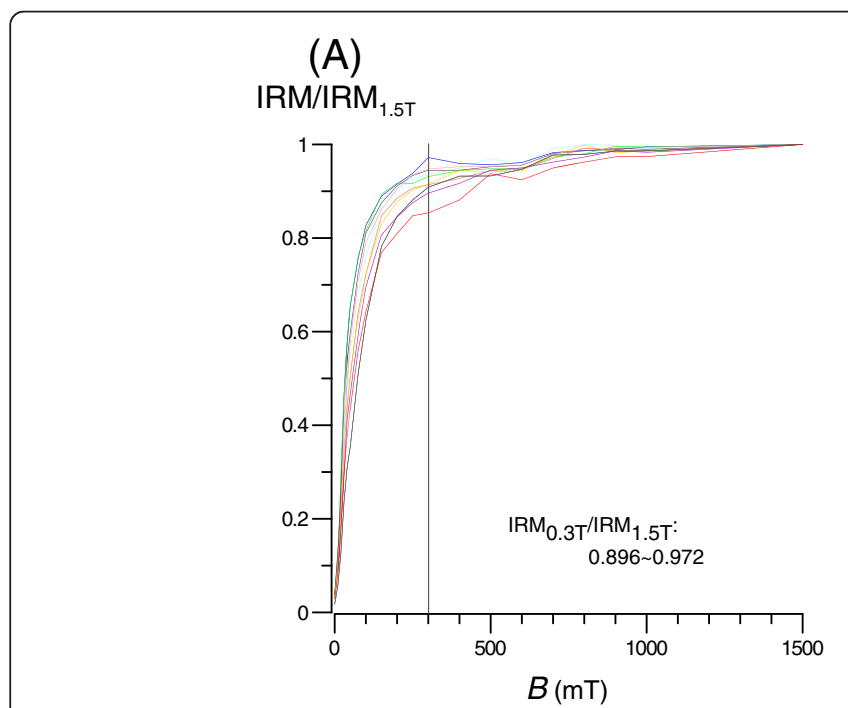

\section{(B)}

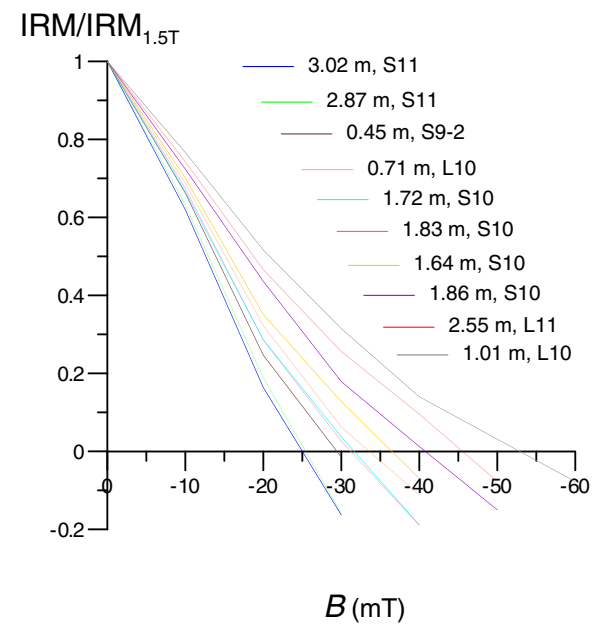

Fig. 3 IRM acquisition curves and backfield curves of IRM for 10 selected samples. a IRM acquisition curves; b backfield curves of IRM. The points of intersection of the curves and the $X$-axis from left to right in (b), the samples are originally from the depth of $3.02 \mathrm{~m}$ (S11), $2.87 \mathrm{~m}$ (S11), $0.45 \mathrm{~m}$ (S9-2), $0.71 \mathrm{~m}$ (L10), $1.72 \mathrm{~m}$ (S10), $1.83 \mathrm{~m}$ (S10), $1.64 \mathrm{~m}$ (S10), $1.86 \mathrm{~m}$ (S10), $2.55 \mathrm{~m}$ (L11), and $1.01 \mathrm{~m}$ (L10), respectively. IRM $\mathrm{IR}_{0.3} \mathrm{~T}\left(\mathrm{IRM}_{1.5} \mathrm{~T}\right)$ represents IRM obtained in the field of $0.3 \mathrm{~T}(1.5 \mathrm{~T})$ 


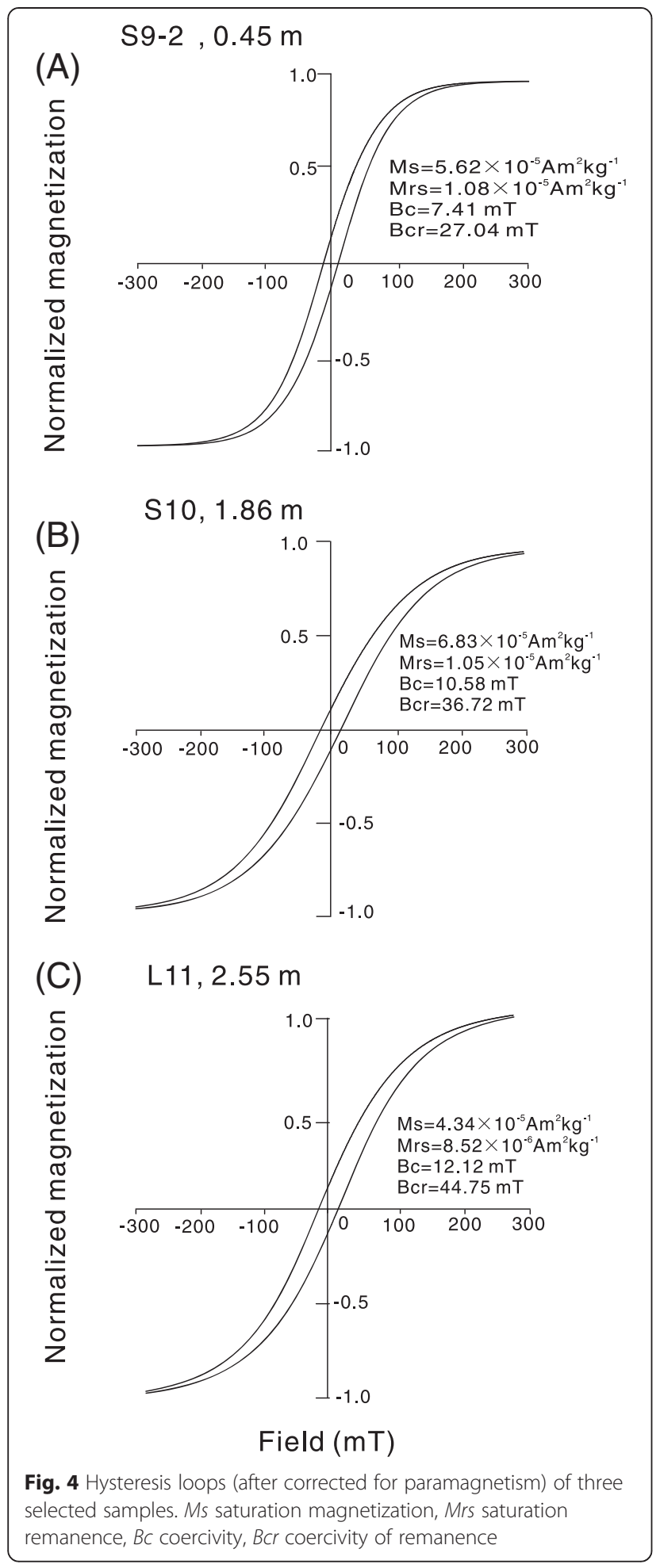

hysteresis parameters of the three samples denote that the average magnetic grain size is distributed in the range of pseudo-single domain (Day et al. 1977; Dunlop 2002), coincident with the previous investigation of the section by Wu et al. (2010).

\section{Anisotropy of magnetic susceptibility}

The principal susceptibility axes that define an ellipsoid with three orthogonal axes for each specimen are labeled as $K_{\mathrm{MAX}}, K_{\mathrm{INT}}$, and $K_{\mathrm{MIN}}\left(K_{\mathrm{MAX}} \geq K_{\mathrm{INT}} \geq K_{\mathrm{MIN}}\right)$. The low-field magnetic susceptibility ( $\chi$, mass specific) in this study was determined by mass-normalized $K_{\mathrm{m}}$ (mean volume susceptibility). The degree of AMS $\left(P=K_{\mathrm{MAX}} /\right.$ $\left.K_{\mathrm{MIN}}\right)$ of the 172 oriented specimens is determined by the foliation $\left(F=K_{\mathrm{INT}} / K_{\mathrm{MIN}}\right)$, which is relatively low and constant and ranges from 1.002 to 1.013 with an average value of 1.005 (Fig. 5b). These values indicate typical characteristics of aeolian sediments as previously suggested (Liu et al. 1988; Zhu et al. 2004; Yang et al. 2010). The majority of specimens demonstrate the prevalence of oblate magnetic fabric (Fig. 5a), which also suggests an aeolian origin. Meanwhile, there is an inverse relationship between $E 12$ and the lineation $\left(L=K_{\mathrm{MAX}} / K_{\mathrm{INT}}\right)$. $E 12$ represents $95 \%$ confidence ellipse half-angle uncertainty between $K_{\text {MAX }}$ and $K_{\text {INT }}$. Only seven specimens had $E 12>22.5^{\circ}$ (Fig. 5c), which indicates a primary sedimentary fabric without apparent disturbance (Lagroix and Banerjee 2004; Zhu et al. 2004).

\section{Paleomagnetism}

A low-temperature natural remanent magnetization (NRM) component can easily be erased below $250{ }^{\circ} \mathrm{C}$, which is generally considered as a viscous remanent magnetization. According to rock magnetic results of the section, the remanent magnetization was dominantly carried by fine-grained magnetite. Most of the specimens have a characteristics remanent magnetization (ChRM) component, which was stable and determined to be between 250 and $585{ }^{\circ} \mathrm{C}$. Representative demagnetization diagrams of six specimens are presented in Fig. 6, including reverse (Fig. 6a, b), normal (Fig. 6e, f), and transitional (Fig. 6c, d) polarities. Particularly in Fig. 6c, the demagnetization trajectories bypass rather than decay toward the origin; thus, the ChRM directions of the specimen at $1.825 \mathrm{~m}$ were not fitted through the origin. The ChRM directions of the other specimens were forced to be computed through the origin.

Of the 172 vertically distributed specimens, 171 yield reliable ChRM directions with maximum angular deviations (MADs) of less than $15^{\circ}$. These specimens were used to construct the magnetic stratigraphy (Fig. 7). One specimen, with a depth of $1.805 \mathrm{~m}$ was not used because a stable ChRM component failed to be isolated. The TJ was clearly identified at the depth of $1.785-1.880 \mathrm{~m}$ in the middle-lower part of the paleosol unit S10. The transition process, which takes into account an average sedimentation rate of about $4.72 \mathrm{~cm} / \mathrm{ka}$ (Wu et al. 2010), was determined to occur over a short duration of ca. $2.02 \mathrm{ka}$. 


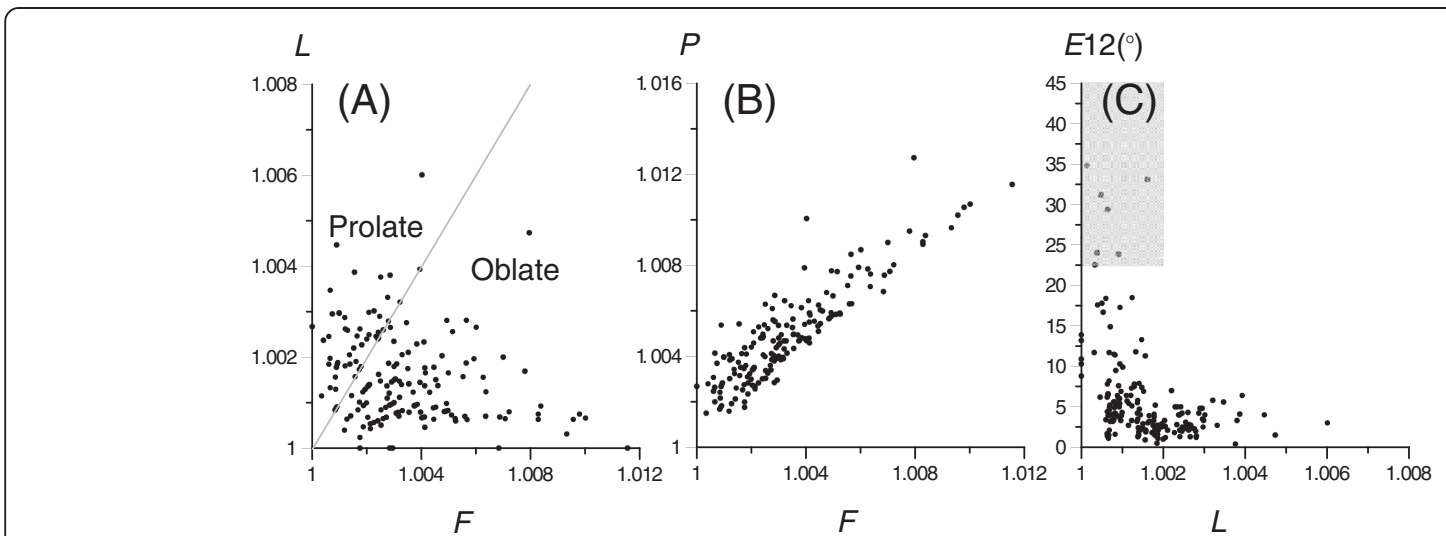

Fig. 5 Plots show the correlation between AMS parameters. a $L\left(=K_{\text {MAX }} / K_{\text {INT }}\right)$ vs $F\left(=K_{\text {INT }} / K_{\text {MIN }}\right), \mathbf{b} P\left(=K_{\text {MAX }} / K_{\text {MIN }}\right)$ vs $F$, and $\mathbf{c} E 12$ vs $L$. The gray area in c envelops specimens with $E 12>22.5^{\circ}$

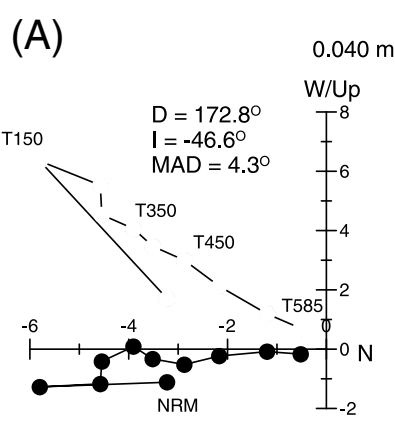

(C) $1.825 \mathrm{~m}$

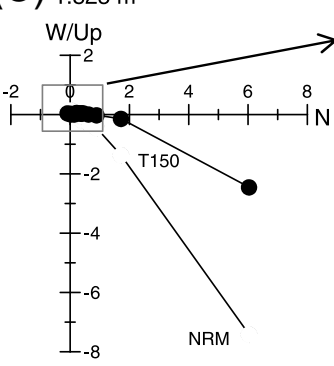

(E) $2.405 \mathrm{~m}$

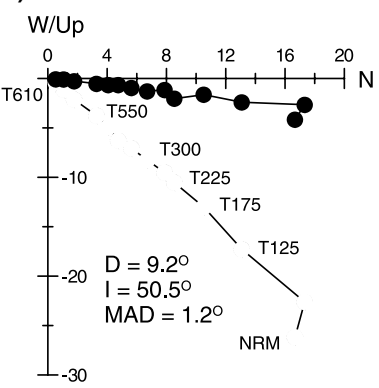

(B) $\quad 0.970 \mathrm{~m}$
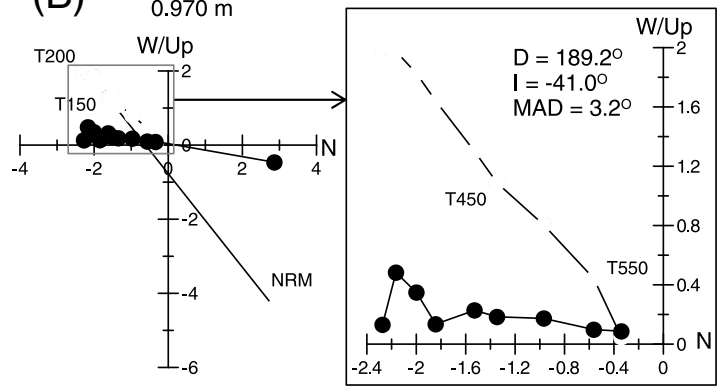

(D) $1.845 \mathrm{~m}$

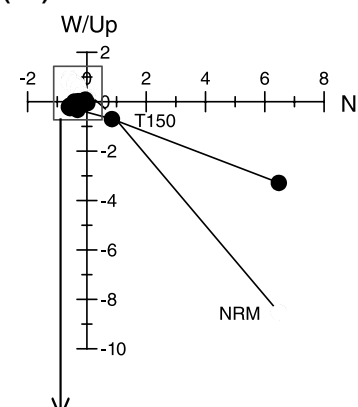

(F) $3.040 \mathrm{~m}$

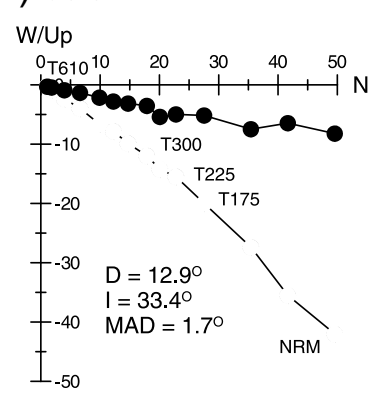

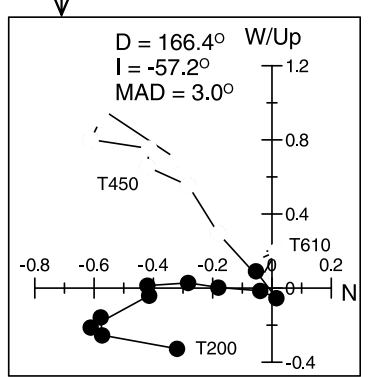

Fig. 6 Demagnetization diagrams of representative specimens after using stepwise thermal demagnetization. The solid and open symbols are for projections onto the horizontal and vertical planes, respectively. The units of thermal demagnetization temperature and coordinate axes are degree Celsius and $\mathrm{mA} / \mathrm{m}$, respectively. Two red dotted lines indicate the fitted routines for the ChRM directions. D declination, / inclination, and MAD maximum angular deviation 


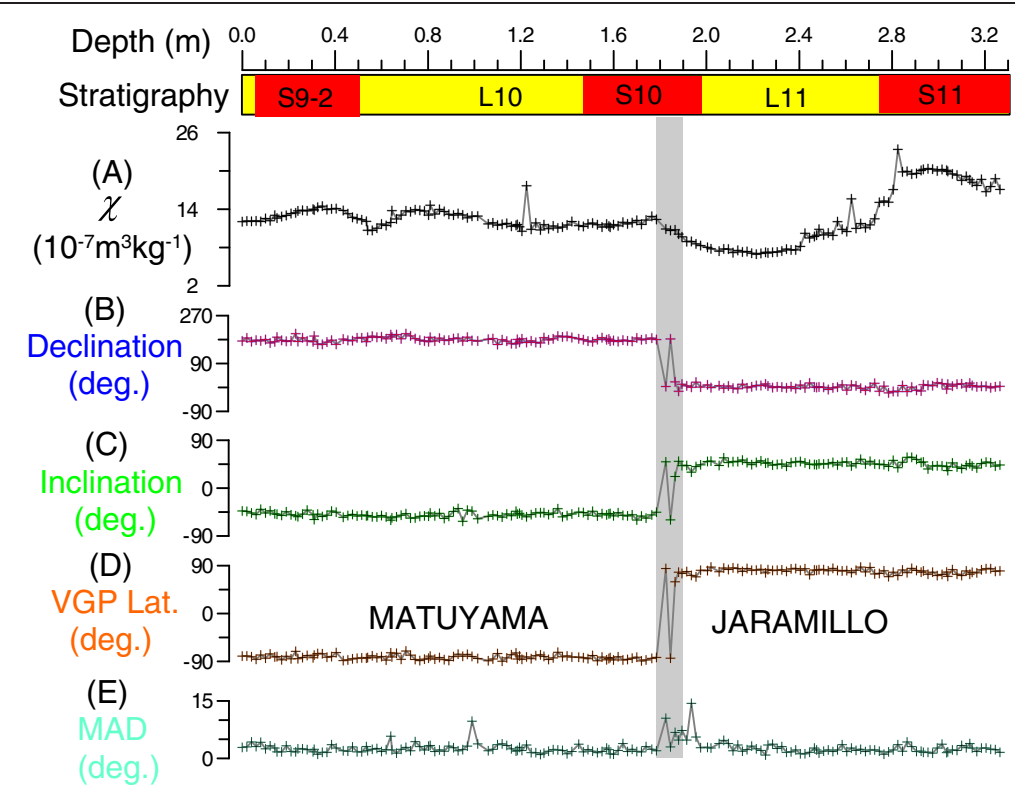

Fig. 7 Magnetic stratigraphy for the studied segment of the Yushan loess section. a $X$, low-field magnetic susceptibility; b, c declination and inclination of the ChRM directions, respectively; d VGP Lat. (virtual geomagnetic pole latitude); e MAD value. A vertical gray belt indicates the transitional polarity zone of the magnetic stratigraphy

\section{Relative paleointensity}

The concentration-dependent parameters, including the $\chi$, ARM, and SIRM, all vary by a factor of less than 4; the magnetic grain-size-dependent parameter ARM/ SIRM varies by a factor of less than 2 (Fig. 8). The relatively constant concentration and grain size of the magnetic minerals satisfy the criteria suggested for construction of relative paleointensity proxies (e.g., Tauxe 1993). The three magnetic-concentration-sensitive parameters, magnetic susceptibility ( $\chi$ or $K_{\mathrm{m}}$ ), ARM, and SIRM, are often used to normalize the NRM for constructing paleomagnetic paleointensity proxies (King et al. 1983; Tauxe 1993; Valet 2003). Here, we use $K_{\mathrm{m}}$ as a normalizer because ARM and SIRM of the specimens from the studied interval of the Yushan section have not been measured. The ratio NRM250/ $K_{\mathrm{m}}$ (NRM250 represents NRM intensity after thermal demagnetization at $250{ }^{\circ} \mathrm{C}$ ) displays a more prominent low at the transitional polarity interval than that within the NRM250 (Fig. 8d, h).

\section{Discussion}

A total of 15 nearly horizontal red-brown paleosol units can be clearly identified in the upper Yushan loess section (Fig. 1c), which allows distinct subdivision of the loess-paleosol sequence. Two marker layers L9 and L15 precisely bracket seven weathered paleosol layers from S91 to S14 in the outcrop. The pedostratigraphy division was confirmed by multiple environmental magnetism parameters (Wu et al. 2010). The magnetic susceptibility record of the segment (from S9-1 to S14) in the Yushan section can be compared to that of the Duanjiapo section
(Bloemendal et al. 2008), which is also located in the Lantian Basin (Fig. 1b) and consists of a continuous and complete sequence of 33 loess-paleosol strata. The segment between 0.65 and $1.0 \mathrm{~m}$ within the Yushan section, which had a period of high $X$ values (Fig. 7a), could not be designated as an unit of weak-weathering paleosol because no soil horizon could be visually or tangibly identified in this interval during the field observation. Three similar segments with relatively high magnetic susceptibility values also appear in the Baoji section, but only two are labeled as the sub-units S9-1 and S9-2 (Yang et al. 2004). The position of TJ in the Yushan section can be connected to the middle-lower part of the paleosol unit S10.

Two complementary tests have been made for the discrimination of the reversal. First, the AMS detected there was no apparent disturbance within the sediment fabric (Figs 5, 8b, c), which suggests a stable postdepositional condition for remanence recording ( $\mathrm{Zhu}$ et al. 2004, 2006; Yang et al. 2004, 2005, 2008, 2010, 2014; Jin and Liu 2010, 2011a, 2011b; Jin et al. 2012). Second, the relative paleointensity proxy $\mathrm{NRM} 250 / K_{\mathrm{m}}$ records a period of obviously low values during the reversal (Fig. 8h). It is generally accepted that geomagnetic field intensity decrease largely during the polarity reversals (Merrill and McFadden 1999). Numerous studies have confirmed the relationship between paleointensities and geomagnetic reversals, such as in marine sediments (e.g., Channell et al. 2002, 2010, 2014; Suganuma et al. 2010; Valet et al. 2014), lacustrine successions (e.g., Sagnotti et al. 2014), ice cores (e.g., Raisbeck et al. 2006), and lavas (e.g., Kissel et al. 2014). Paleomagnetic and rock magnetic studies also have 


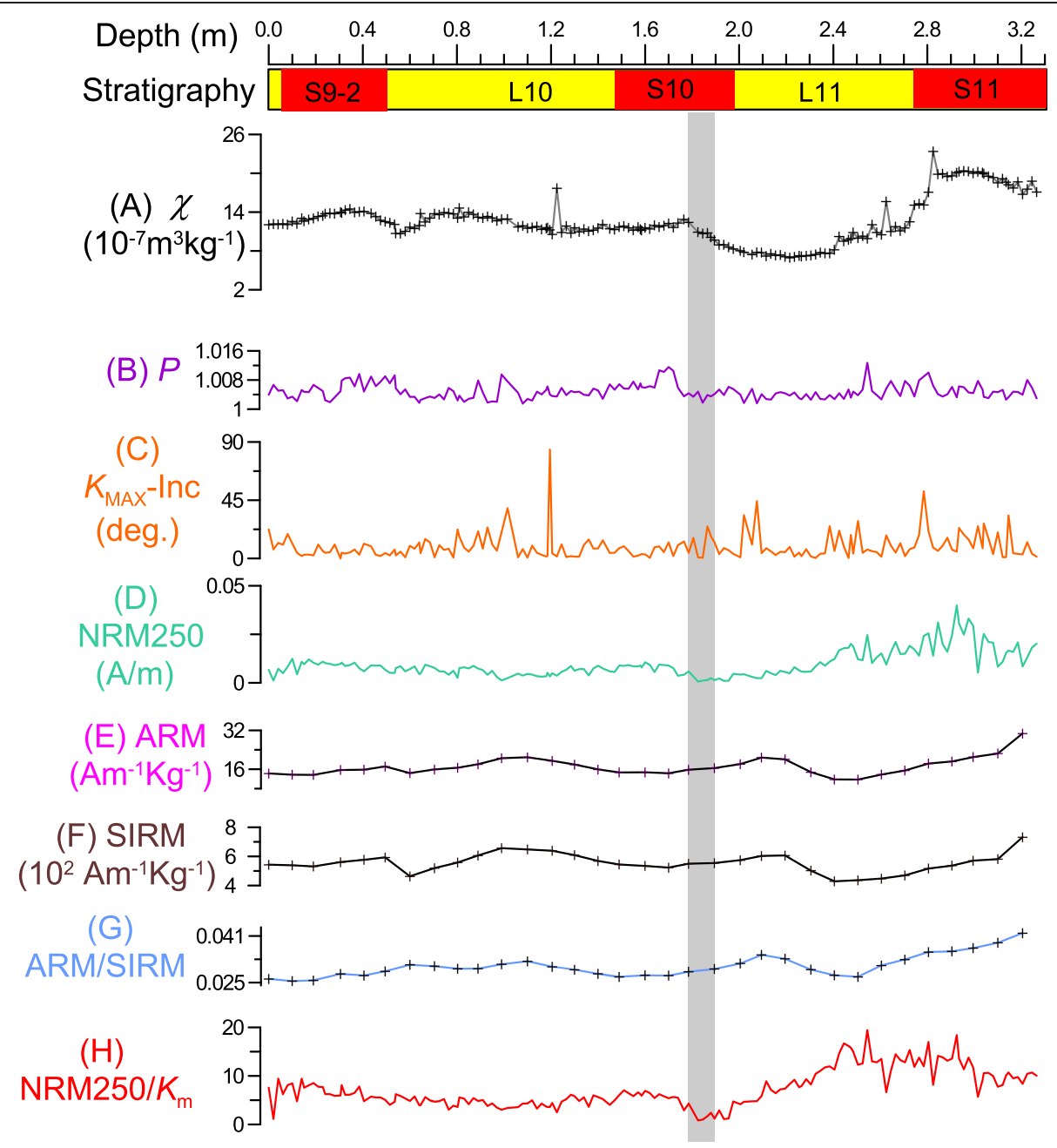

Fig. 8 Summary of magnetic results for the studied segment of the Yushan loess section. a $x$, low-field magnetic susceptibility; $\mathbf{b} P$ (the degree of AMS); $\mathbf{c} K_{\text {MAX }}$-Inc (inclination of the maximum axis); $\mathbf{d}$ NRM250; e ARM; $\mathbf{f}$ SIRM; $\mathbf{g}$ ARM/SIRM; $\mathbf{h}$ NRM250/Km. Please see details in the text. The ARM and SIRM data of 38 samples used here have been previous reported by Wu et al. (2010)

reported reliable connection between paleointensity and geomagnetic reversals recorded in Chinese loess (e.g., Jin and Liu 2010; Yang et al. 2012). The paleointensity proxy low recorded in the interval of $1.785-1.880 \mathrm{~m}$ in the Yushan section thus confirms the stratigraphic position where the geomagnetic reversal of $\mathrm{TJ}$ is recorded.

However, the position of the reversal differs from previous records in loess sections across the CLP. A recent paleomagnetic study from the Baoji loess section defined the TJ at the top of L10 (Yang et al. 2004), which is in agreement with previous studies in the same area (Rutter et al. 1990). The TJ was also placed in L10 from the loess sections of Weinan at the southern CLP (Zhu et al. 1994; Pan et al. 2002), and Xifeng in the central CLP (Liu et al. 1988), and close to the stratigraphy boundary of the L10/S9 in the section of Jingbian at the northern CLP (Guo et al. 2002). Meanwhile, a series of studies from other loess sections, such as Luochuan in the central CLP (Heller and
Liu 1984; Kukla and An 1989; Liu et al. 2010), Duanjiapo at the southern CLP (Zheng et al. 1992), and Sanmenxia at the southeastern CLP (Wang et al. 2005, 2006) defined the final position of the TJ in the paleosol unit of S10. Jin and Liu (2011a) put the TJ in the middle-lower S10 of the classical Luochuan section but present no paleomagnetic data for the reversal. Thus, we still use the position of the TJ provided by Liu et al. (2010) in Fig. 9. Furthermore, these records largely indicate a more or less higher position for the TJ than that for this study (refer to Fig. 9). Fortunately, previous age determination within the TJ could shed light on its exact stratigraphic position in the loesspaleosol sequence of China. A recent paleomagnetic and dating (K-Ar and ${ }^{40} \mathrm{Ar} /{ }^{39} \mathrm{Ar}$ ) investigation on volcanic rocks at Canary Islands reported that the centered age of the TJ is at $996 \pm 7 \mathrm{ka}(2 \sigma$, relative to $\mathrm{FC}$ sanidine at 28.02 Ma) (Kissel et al. 2014). This age is consistent with the ${ }^{40} \mathrm{Ar} /{ }^{39} \mathrm{Ar}$ age (a weighted mean of 


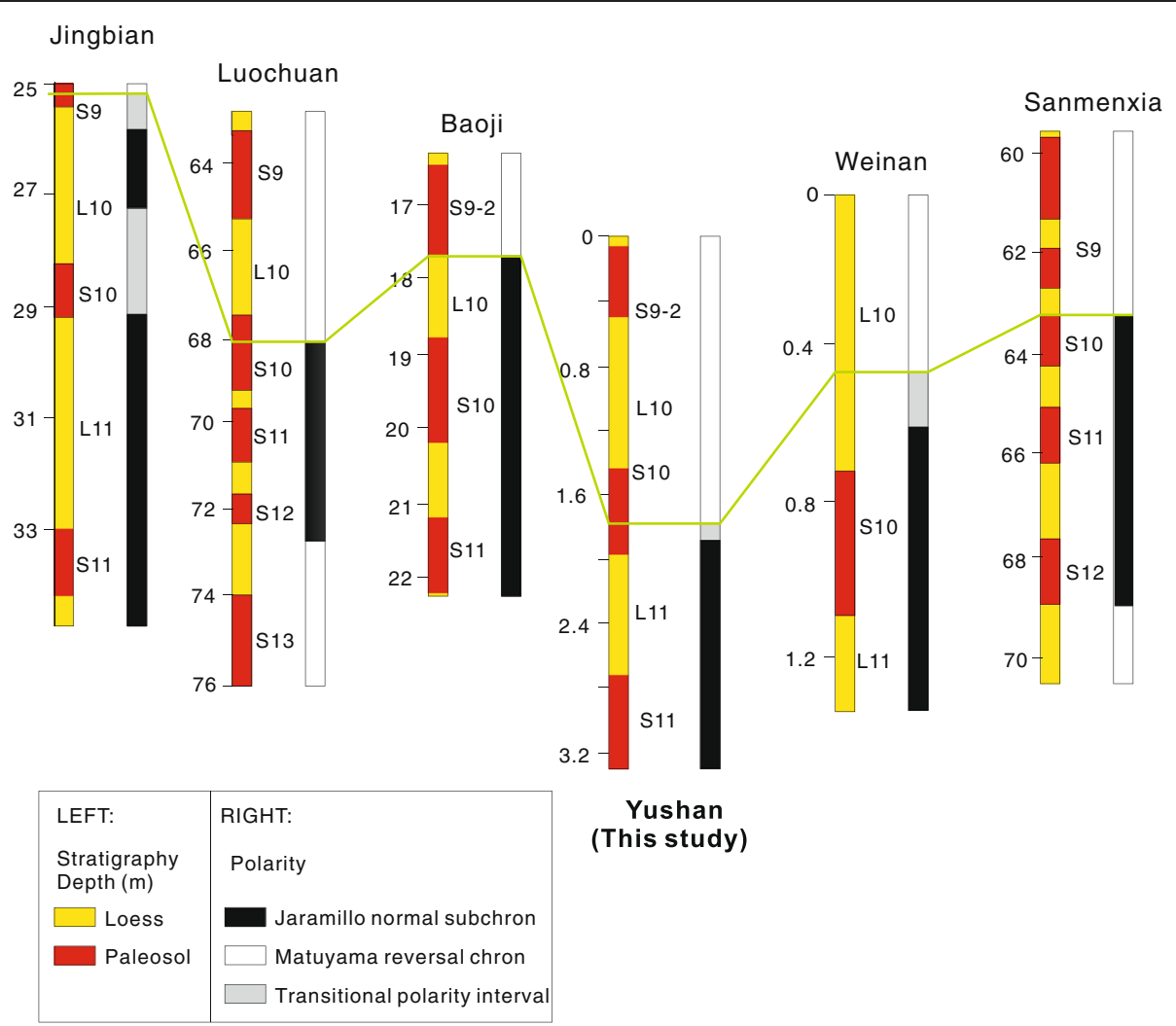

Fig. 9 Comparison of the magnetic stratigraphy results of the TJ in Chinese loess. Data resources: Jingbian from Guo et al. (2002); Luochuan from Liu et al. (2010); Baoji from Yang et al. (2004); Weinan from Zhu et al. (1994); and Samenxia from Wang et al. (2005)

$1001 \pm 10 \mathrm{ka})$ of the TJ obtained from the lava flows in the Punaruu Valley in Tahiti (Singer 2014). The most suitable age for the TJ could be obtained from reconciliation of radiometric dating on volcanic rocks (Kissel et al. 2014; Singer 2014) and chronological framework of global deep-sea sediments (Shackleton et al. 1990; Channell et al. 2002, 2009; Horng et al. 2002; Yamazaki and Oda 2002, 2005; Lisiecki and Raymo 2005; Mazaud et al. 2009), which yield an age of ca. $990 \mathrm{ka}$. This timing correlates with the top of the loess unit L10 in the "Chiloparts" (Chinese loess particle timescale) given a reference age of the bottom of S9-2 at 989 ka (Ding et al. 2002). The Chiloparts was established by tuning grain size records of five loess sections over the CLP to the theoretical variations in obliquity and precession of the Earth's orbit. Thus, there will be an offset of ca. $1.23 \mathrm{~m}$ in depth between the position of the $\mathrm{TJ}$ in this study (at ca. $1.78 \mathrm{~m}$ ) and the one oriented from the Chiloparts (at ca. $0.52 \mathrm{~m}$ ). If the S9-2 is relocated to the depth of $0.65-1.0 \mathrm{~m}$, the offset depth will be ca. $0.78 \mathrm{~m}$. This may imply the TJ has been displaced downward in the Yushan section. The downward shift could be attributed to the lock-in effect, which has been identified in Chinese loess (Zhou and Shackleton 1999; Heslop et al. 2000; Spassov et al. 2003). We suggest that the almost lowest position of the $\mathrm{TJ}$ in the Yushan section should be ascribed to a deeper lock-in depth compared to its counterparts in Chinese loess.

Meanwhile, we note that Jin and Liu (2011a) recently proposed a new division of S9-S10. According to their strategy, S10 should consist of two sub-paleosol units (former S9-2 and S10), then it could be well-correlated to the two weak interglacials of marine isotope stage (MIS) 27 in marine sediments. A similar strategy was proposed to deal with the long-standing discrepancy of Matuyama-Brunhes boundary (MBB) between Chinese loess and marine sediments (e.g., Wang et al. 2006; Liu et al. 2008; Jin and Liu 2011b). These adjustments would bring the marine and terrestrial records into better age agreements for both the TJ and MBB but might result in a confused correlation of Chinese loess-paleosol sequences and marine sediments (e.g., Zhao et al. 2014; Zhou et al. 2014).

Therefore, an alternative explanation for the relatively deeper TJ in the Yushan section would still be a lock-in model. This is supported by an investigation of the timing and lock-in effect of the Laschamp geomagnetic excursion in Chinese loess, which indicated a progressive southeastward increase in the lock-in depth in three loess sections across the CLP (Sun et al. 2013). Complicated regional geology and paleoenvironmental backgrounds, such as 
frequent tectonic activity (Sun 2005) and water content in loess (Wang and Løvlie 2010; Zhao and Roberts 2010), might play a significant role during deposition and final consolidation of aeolian dusts. Obvious differences, such as the stratigraphic position and transitional process of the reversal, are seen in the two neighboring sections, i.e. the Weinan and Yushan loess sections (Fig. 9), and might result from different postdepositional remanent magnetization processes induced by varying sedimentary characteristics and environments from area to area (Sun et al. 2013).

Moreover, the duration of the reversal determined by a very limited number of specimens from this study, ca. $2.02 \mathrm{ka}$, differs from previous studies, such as ca. $3.2 \mathrm{ka}$ from the Weinan section (Zhu et al. 1994), $7.6 \mathrm{ka}$ with an uncertainty of $5.6 \mathrm{ka}$ from a volcanic section at Tenerife, Canary Islands (Kissel et al. 2014) and ca. 8 ka on deep-sea sediments (ca. $8 \mathrm{ka}$ ) (Channell et al. 2009).

\section{Conclusions}

We identify the stratigraphic position of the TJ in the middle-lower part of the paleosol unit S10 in the Yushan section at the southern margin of CLP through a paleomagnetic and rock magnetic study with nearcontinuous sampling. We primarily attribute this characteristic recording to a deep lock-in depth of remanence acquisition. Regionally complex geological background and paleoenvironmental conditions may have played an important role in the remanence acquisition in loess during the postdepositional process. Additionally, the exact location of the reversal is important for future reliable age determinations of Paleolithic sites discovered in loess from the Lantian Basin (Zhang et al. 1978; An and Ho 1989; Zhu et al. 2015; Dennell, in press). These sites often lack a continuous and complete loesspaleosol sequence when referring to a classical frame sequence of loess (e.g., Ding et al. 2002; Sun et al. 2006).

\section{Abbreviations \\ AMS: anisotropy of magnetic susceptibility; ARM: anhysteretic remanent magnetization; Bc: coercivity; Bcr: coercivity of remanence; Chiloparts: Chinese loess particle timescale; ChRM: characteristics remanent magnetization; CLP: Chinese Loess Plateau; F: foliation; IRM: isothermal remanent magnetization; $K_{\mathrm{m}}$ : mean volume susceptibility; $L$ : lineation; MAD: maximum angular deviation; Mrs: saturation remanence; Ms: saturation magnetization; NRM: natural remanent magnetization; NRM250: NRM after thermal demagnetization at $250^{\circ} \mathrm{C}$; SIRM: saturation isothermal remanent magnetization; ThD: thermal demagnetization; TJ: termination of the Jaramillo subchron; $x$ : low-field magnetic susceptibility.}

\section{Competing interests}

The authors declare that they have no competing interests.

\section{Authors' contributions}

YW and ZZ designed the study. YW directed the experiments and wrote the first draft of the manuscript. YW, TO, SQ, and ZR performed the experiments. YW, SQ, ZR, and ZZ took part in the field work. All the authors contributed to the discussion of the results and approved the final manuscript.

\section{Acknowledgements}

We acknowledge the assistance in paleomagnetic sampling by Drs. Cai Jianxin, Han Jiangwei, and Zou Yi. We thank Professor Tan Xiaodong for laboratory guidance at SCSIO, CAS. We are also grateful to Professor Liu Xiuming and Dr Lü Bin for their kindly help in magnetism measurements made in Lanzhou University. Financial support was provided by grants from the National Basic Research Program of China (2010CB833405) and the National Natural Science Foundation of China $(41102115,40930106)$.

\section{Author details}

'Key Laboratory of Marginal Sea Geology, South China Sea Institute of Oceanology, Chinese Academy of Sciences, Guangzhou 510301, China. ${ }^{2}$ Key Laboratory of Marginal Sea Geology, Guangzhou Institute of Geochemistry, Chinese Academy of Sciences, Guangzhou 510640, China. ${ }^{3}$ School of Geography and Planning, Gannan Normal University, Ganzhou 341000, China. ${ }^{4}$ Key Laboratory of Western China's Environmental Systems (Ministry of Education), College of Earth and Environmental Sciences, Lanzhou University, Lanzhou 730000, China.

Received: 22 July 2015 Accepted: 6 October 2015

Published online: 20 October 2015

\section{References}

An Z, Ho C (1989) New magnetostratigraphic dates of Lantian Homo erectus. Quat Res 32:213-21. doi:10.1016/0033-5894(89)90077-X

An Z, Kukla GJ, Porter SC, Xiao J (1991) Magnetic susceptibility evidence of monsoon variation on the Loess Plateau of central China during the last 130,000 years. Quat Res 36:29-36. doi:10.1016/0033-5894(91)90015-W

Bloemendal J, Liu X, Sun Y, Li N (2008) An assessment of magnetic and geochemical indicators of weathering and pedogenesis at two contrasting sites on the Chinese Loess Plateau. Palaeogeogr Palaeoclimatol Palaeoecol 257:152-68. doi:10.1016/.jpalaeo.2007.09.017

Burbank DW, Li J (1985) Age and palaeoclimatic significance of the loess of Lanzhou, north China. Nature 316:429-31. doi:10.1038/316429a0

Cande SC, Kent DV (1995) Revised calibration of the geomagnetic polarity timescale for the Late Cretaceous and Cenozoic. J Geophys Res 100(B4):6093-5. doi:10.1029/94JB03098

Channell JET, Mazaud A, Sullivan P, Turner S, Raymo ME (2002) Geomagnetic excursions and paleointensities in the Matuyama Chron at Ocean Drilling Program Sites 983 and 984 (Iceland Basin). J Geophys Res 107:B6. doi:10.1029/2001JB000491

Channell JET, Xuan C, Hodell DA (2009) Stacking paleointensity and oxygen isotope data for the last 1.5 Myr (PISO-1500). Earth Planet Sci Lett 283(1):14-23. doi:10.1016/j.epsl.2009.03.012

Channell JET, Hodell DA, Singer BS, Xuan C (2010) Reconciling astrochronological and ${ }^{40} \mathrm{Ar} /{ }^{39} \mathrm{Ar}$ ages for the Matuyama-Brunhes boundary and late Matuyama chron. Geochem Geophys Geosyst 11:Q0AA12. doi:10.1029/2010GC003203

Channell JET, Wright JD, Mazaud A, Stoner JS (2014) Age through tandem correlation of Quaternary relative paleointensity (RPI) and oxygen isotope data at IODP Site U1306 (Eirik Drift, SW Greenland). Quat Sci Rev 88:135-46. doi:10.1016/j.quascirev.2014.01.022

Cogné JP (2003) PaleoMac: a Macintosh ${ }^{\top M}$ application for treating paleomagnetic data and making plate reconstructions. Geochem Geophys Geosyst 4:1007. doi:10.1029/2001GC000227

Day R, Fuller M, Schmidt VA (1977) Hysteresis properties of titanomagnetites: grain-size and compositional dependence. Phys Earth Planet Inter 13:260-7. doi:10.1016/0031-9201(77)90108-X

Dennell RW. The Jaramillo Subchron, a geochronological marker horizon in the palaeoanthropological record of China. Quat Int. doi:10.1016/ j.quaint.2014.11.006 (in press)

Ding ZL, Liu TS, Liu XM, Chen MY, An ZS (1990) Thirty-seven climatic cycles in the last 2.6 Ma. Chin Sci Bull 34:1494-6

Ding Z, Yu Z, Rutter NW, Liu T (1994) Towards an orbital time scale for Chinese Loess Plateau. Quat Sci Rev 13:39-70. doi:10.1016/0277-3791(94)90124-4

Ding ZL, Derbyshire E, Yang SL, Yu ZW, Xiong SF, Liu TS (2002) Stacked 2.6-Ma grain size record from the Chinese loess based on five sections and correlation with the deep-sea $\delta^{18} \mathrm{O}$ record. Paleoceanograp. 17. doi:10.1029/2001PA000725.

Dunlop DJ (2002) Theory and application of the day plot $\left(M_{r s} / M_{s}\right.$ versus $\left.H_{c r} / H_{c}\right): 1$. Theoretical curves and tests using titanomagnetite data. J Geophys Res 107(B3):2056. doi:10.1029/2001JB000486 
Enkin R, Wuolle K, Mccann C, Carretero M, Voroney M, Baylis T, Morton K, Jaycock D, Baker J, Beran L (2003) PMGSC - Paleomagnetism Data Analysis, ver. 4.2., Geological Survey of Canada.

Fang XM, Li JJ, Van der Voo R, MacNiocaill C, Dai RX, Kemp RA, Derbyshire E, Cao JX, Wang JM, Wang G (1997) A record of the Blake event during the last interglacial interglacial paleosol in the western Loess Plateau of China. Earth Planet Sci Lett 146:73-82. doi:10.1016/S0012-821X(96)00222-1

Florindo F, Zhu R, Guo B, Yue L, Pan Y, Speranza F (1999) Magnetic proxy climate results from the Duanjiapo loess section, southernmost extremity of the Chinese loess plateau. J Geophys Res: Solid Earth (1978-2012). J Geophys Res Solid Earth 104(B1):645-59. doi:10.1029/1998JB900001

Guo B, Zhu R, Florindo F, Ding Z, Sun J (2002) A short, reverse polarity interval within the Jaramillo subchron: evidence from the Jingbian section, northern Chinese Loess Plateau. J Geophys Res: Solid Earth (1978-2012) 107(B6):EPM-2. doi:10.1029/2001JB000706

Heller F, Liu T (1982) Magnetostratigraphical dating of loess deposits in China. Nature 300:431-3. doi:10.1038/300431a0

Heller F, Liu T (1984) Magnetism of Chinese loess deposits. Geophys J Int 77(1):125-41. doi:10.1111/j.1365-246X.1984.tb01928.x

Heslop D, Langereis CG, Dekkers MJ (2000) A new astronomical timescale for the loess deposits of Northern China. Earth Planet Sci Lett 184:125-39. doi:10.1016/S0012-821X(00)00324-1

Horng CS, Lee MY, Pälike H, Wei KY, Liang WT, lizuka Y, Torii M (2002) Astronomically calibrated ages for geomagnetic reversals within the Matuyama chron. Earth Planets Space 54(6):679-90

Jelínek V (1978) Statistical processing of anisotropy of magnetic susceptibility measured on groups of specimens. Stud Geophys Geod 22:50-62. doi:10.1007/BF01613632

Jin C, Liu Q (2010) Reliability of the natural remanent magnetization recorded in Chinese loess. J Geophys Res 115:B4. doi:10.1029/2009JB006703

Jin C, Liu Q (2011a) Remagnetization mechanism and a new age model for L9 in Chinese loess. Phys Earth Planet Inter 187:261-75. doi:10.1016/j.pepi.2011.03.010

Jin C, Liu Q (2011b) Revisiting the stratigraphic position of the Matuyama-Brunhes geomagnetic polarity boundary in Chinese loess. Palaeogeog Palaeoclimat Palaeoecol 299:309-17. doi:10.1016/j.palaeo.2010.11.011

Jin C, Liu Q, Larrasoana JC (2012) A precursor to the Matuyama-Brunhes reversal in Chinese loess and its palaeomagnetic and stratigraphic significance. Geophys J Int 19:829-42. doi:10.1111/j.1365-246X.2012.05537.x

King JW, Banerjee SK, Marvin J (1983) A new rock magnetic approach to selecting sediments for geomagnetic paleointensity studies: application to paleointensity for the last 4000 years. J Geophys Res: Solid Earth (1978-2012) 88(B7):5911-21. doi:10.1029/JB088iB07p05911

Kirschvink JL (1980) The least-squares line and plane and the analysis of palaeomagnetic data. Geophys J R Astron Soc 62:699-718. doi:10.1111/ j.1365-246X.1980.tb02601.x

Kissel C, Guillou H, Laj C, Carracedo JC, Perez-Torrado F, Wandres C, RodriguezGonzalez A, Nomade S (2014) A combined paleomagnetic/dating investigation of the upper Jaramillo transition from a volcanic section at Tenerife (Canary Islands). Earth Planet Sci Lett 406:59-71. doi:10.1016/ j.epsl.2014.09.003

Kukla G (1987) Loess stratigraphy in central China. Quat Sci Rev 6:191-219. doi:10.1016/0277-3791(87)90004-7

Kukla G, An ZS (1989) Loess stratigraphy in central China. Palaeogeog Palaeoclimat Palaeoecol 72:203-25

Kukla G, Heller F, Liu XM, Xu TC, Liu TS, An ZS (1988) Pleistocene climates in China dated by magnetic susceptibility. Geology 16:811-4. doi:10.1130/00917613(1988)016<0811:PCICDB>2.3.CO:2

Lagroix F, Banerjee SK (2004) The regional and temporal significance of primary weolian magnetic fabrics preserved in Alaskan loess. Earth Planet Sci Lett 225:379-95. doi:10.1016/j.epsl.2004.07.003

Leonhardt R (2006) Analyzing rock magnetic measurements: the RockMagAnalyzer 1.0 software. Comput Geosci 32:1420-31. doi:10.1016/ j.cageo.2006.01.006

Lisiecki LE, Raymo ME (2005) A Pliocene-Pleistocene stack of 57 globally distributed benthic $\delta^{18} \mathrm{O}$ records. Paleoceanography 20:PA1003. doi:10.1029/ 2004PA001071

Liu TS (1985) Loess and the environment. China Ocean Press, Beijing

Liu XM, Liu TS, Xu TC, Liu C, Chen MY (1988) The Chinese loess in Xifeng, I. The primary study on magnetostratigraphy of a loess profile in Xifeng area, Gansu province. Geophys J R Astron Soc 92:345-8. doi:10.1111/j.1365246X.1988.tb01146.x
Liu Q, Roberts AP, Rohling EJ, Zhu R, Sun Y (2008) Post-depositional remanent magnetization lock-in and the location of the Matuyama-Brunhes geomagnetic reversal boundary in marine and Chinese loess sequences. Earth Planet Sci Lett 275:102-10. doi:10.1016/j.epsl.2008.08.004

Liu W, Zhang L, Sun J (2010) High resolution magnetostratigraphy of the Luochuan loess-paleosol sequence in the central Chinese Loess Plateau. Chinese J Geophys 53(4):888-94. doi:10.3969/j.issn.0001-5733.2010.04.013

Liu Q, Jin C, Hu P, Jiang Z, Ge K, Roberts AP (2015) Magnetostratigraphy of Chinese loess-paleosol sequences. Earth Sci Rev 150:139-67. doi:10.1016/ j.earscirev.2015.07.009

Lu H, Liu X, Zhang F, An Z, Dodson J (1999) Astronomical calibration of loesspaleosol deposits at Luochuan, central Chinese Loess Plateau. Palaeogeog Palaeoclimat Palaeoecol 154:237-46. doi:10.1016/S0031-0182(99)00113-3

Mazaud A, Channell JET, Xuan C, Stoner JS (2009) Upper and lower Jaramillo polarity transitions recorded in IODP Expedition 303 North Atlantic sediments: implications for transitional field geometry. Phys Earth Planet Inter 172(3):131-40. doi:10.1016/j.pepi.2008.08.012

Merrill RT, McFadden PL (1999) Geomagnetic polarity transitions. Rev Geophys 37:201-26. doi:10.1029/1998RG900004

Pan YX, Zhu RX, Liu QS, Guo B, Yue LP, Wu HN (2002) Geomagnetic episodes of the last 1.2 Myr recorded in Chinese loess. Geophys Res Lett 29:123-1. doi:10.1029/2001GL014024

Porter S, An Z (1995) Correlation between climate events in the North Atlantic and China during the last glaciation. Nature 375:305-8. doi:10.1038/375305a0

Raisbeck GM, Yiou F, Cattani O, Jouzel J (2006) 10Be evidence for the MatuyamaBrunhes geomagnetic reversal in the EPICA Dome C ice core. Nature 444:82-4 doi:10.1038/nature05266

Roberts AP, Cui Y, Verosub KL (1995) Wasp-waisted hysteresis loops: mineral magnetic characteristics and discrimination of components in mixed magnetic systems. J Geophys Res Solid Earth 100(B9):17909-24. doi:10.1029/ 95JB00672

Rolph TC, Shaw J, Derbyshire E, Wang J (1989) A detailed geomagnetic record from Chinese loess. Phys Earth Planet Inter 56:151-64. doi:10.1016/00319201(89)90044-7

Rutter N, Ding Z, Evans ME, Wang Y (1990) Magnetostratigraphy of the Baoji loess-paleosol section in the north-central China Loess Plateau. Quat Int 7(8):91-102. doi:10.1016/1040-6182(90)90043-4

Sagnotti L, Scardia G, Giaccio B, Liddicoat JC, Nomade S, Renne PR, Sprain CJ (2014) Extremely rapid directional change during Matuyama-Brunhes geomagnetic polarity reversal. Geophys J Int 199(2):1110-24. doi:10.1093/gji/ggu287

Shackleton NJ, Berger A, Peltier WR (1990) An alternative astronomical calibration of the lower Pleistocene based on ODP Site 677. Trans R Soc Edin 81:251-61

Singer BS (2014) A Quaternary geomagnetic instability time scale. Quat Geochronol 21:29-52. doi:10.1016/j.quageo.2013.10.003

Spassov S, Heller F, Evans ME, Yue LP, Ding ZL (2001) The Matuyama/Brunhes geomagnetic polarity transition at Lingtai and Baoji, Chinese loess plateau. Phys Chem Earth Part A 26:899-904. doi:10.1016/S1464-1895(01)00139-9

Spassov S, Heller F, Evans ME, Yue LP, Tv D (2003) A lock-in model for the complex Matuyama-Brunhes boundary record of the loess/palaeosol sequence at Lingtai (Central Chinese Loess Plateau). Geophys J Int 155:350-66. doi:10.1046/j.1365-246X.2003.02026.x

Suganuma Y, Yokoyama Y, Yamazaki T, Kawamura K, Horng CS, Matsuzaki H (2010) Be evidence for delayed acquisition of remanent magnetization in marine sediments: implication for a new age for the Matuyama-Brunhes boundary. Earth Planet Sci Lett 296(3):443-50. doi:10.1016/j.epsl.2010.05.031

Sun J (2005) Long-term fluvial archives in the Fen Wei Graben, central China, and their bearing on the tectonic history of the India-Asia collision system during the Quaternary. Quat Sci Rev 24:1279-86. doi:10.1016 j.quascirev.2004.08.018

Sun D, Shaw J, An Z, Rolph T (1993) Matuyama/Brunhes (M/B) transition recorded in Chinese loess. J Geomag Geoelec 45:319-30

Sun Y, Clemens SC, An Z, Yu Z (2006) Astronomical timescale and palaeoclimatic implication of stacked 3.6-Myr monsoon records from the Chinese Loess Plateau. Quat Sci Rev 25:33-48. doi:10.1016/j.quascirev.2005.07.005

Sun Y, Qiang X, Liu Q, Bloemendal J, Wang X (2013) Timing and lock-in effect of the Laschamp geomagnetic excursion in Chinese Loess. Geochem Geophys Geosyst 14(11):4952-61. doi:10.1002/2013GC004828

Tauxe $L$ (1993) Sedimentary records of relative paleointensity of the geomagnetic field: theory and practice. Rev Geophys 31:319-54. doi:10.1029/93RG01771 
Tauxe L, Mullender TAT, Pick T (1996) Potbellies, wasp-waists, and superparamagnetism in magnetic hysteresis. J Geophys Res: Solid Earth (1978-2012) 101(B1):571-83. doi:10.1029/95JB03041

Valet JP (2003) Time variations in geomagnetic intensity. Rev Geophys 41:1. doi:10.1029/2001RG000104

Valet JP, Bassinot F, Bouilloux A, Bourlès D, Nomade S, Guillou V, Lopes F, Thouveny N, Dewilde F (2014) Geomagnetic, cosmogenic and climatic changes across the last geomagnetic reversal from Equatorial Indian Ocean sediments. Earth Planet Sci Lett 397:67-79. doi:10.1016/ j.epsl.2014.03.053

Wang R, Løvlie R (2010) Subaerial and subaqueous deposition of loess: experimental assessment of detrital remanent magnetization in Chinese loess. Earth Planet Sci Lett 298:394-404. doi:10.1016/j.epsl.2010.08.019

Wang X, Løvlie R, Yang Z, Pei J, Zhao Z, Sun Z (2005) Remagnetization of Quaternary eolian deposits: a case study from SE Chinese Loess Plateau. Geochem Geophys Geosyst 6:6. doi:10.1029/2004GC000901

Wang X, Yang Z, Løvlie R, Sun Z, Pei J (2006) A magnetostratigraphic reassessment of correlation between Chinese loess and marine oxygen isotope records over the last 1.1 Ma. Phys Earth Planet Inter 159(1):109-17. doi:10.1016/j.pepi.2006.07.002

Wang X, Løvlie R, Chen Y, Yang Z, Pei J, Tang L (2014) The Matuyama-Brunhes polarity reversal in four Chinese loess records: high-fidelity recording of geomagnetic field behavior or a less than reliable chronostratigraphic marker? Quat Sci Rev 101:61-76. doi:10.1016/j.quascirev.2014.07.005

Wu Y, Zhu Z, Rao Z, Qiu S, Yang T (2010) Mid-late Quaternary loess-paleosol sequence in Lantian's Yushan, China: an environmental magnetism approach and its paleoclimatic significance. Chin Sci Bull 55:2989-3000. doi:10.1007/ s11434-010-3212-6

Wu Y, Zhu Z, Qiu S, Rao Z (2013) A rock magnetic record of Asian cooling and aridification processes during 1.95-0.40 Ma in the southeastern Chinese Loess Plateau. Chin Sci Bull 58(30):3636-44. doi:10.1007/s11434-013-5775-5

Yamazaki T, Oda H (2002) Orbital influence on Earth's magnetic field: 100,000year periodicity in inclination. Science 295:2435-8. doi:10.1126/ science.1068541

Yamazaki T, Oda H (2005) A geomagnetic paleointensity stack between 0.8 and 3.0 Ma from equatorial Pacific sediment cores. Geochem Geophys Geosyst 6(11):Q11H20. doi:10.1029/2005GC001001

Yang S, Ding Z (2010) Drastic climatic shift at $\sim 2.8 \mathrm{Ma}$ as recorded in eolian deposits of China and its implications for redefining the Pliocene-Pleistocene boundary. Quat Int 219(1):37-44. doi:10.1016/j.quaint.2009.10.029

Yang T, Hyodo M, Yang Z, Fu J (2004) Evidence for the Kamikatsura and Santa Rosa excursions recorded in eolian deposits from the southern Chinese Loess Plateau. J Geophys Res: Solid Earth (1978-2012) 109:B12. doi:10.1029/ 2004JB002966

Yang T, Hyodo M, Yang Z, Sun Z (2005) A first paleomagnetic and rock magnetic investigation of calcareous nodules from the Chinese Loess Plateau. Earth Planets Space 57(1):29-34

Yang T, Hyodo M, Yang Z, Ding L, Fu J, Mishima T (2007a) Early and middle Matuyama geomagnetic excursions recorded in the Chinese loess-paleosol sediments. Earth Planets Space 59(7):825-40

Yang T, Hyodo M, Yang Z, Fu J (2007b) Two geomagnetic excursions during the Brunhes chron recorded in Chinese loess-palaeosol sediments. Geophys J Int 171:104-14. doi:10.1111/j.1365-246X.2007.03522.x

Yang T, Hyodo M, Yang Z, Ding L, Li H, Fu J, Wang S, Wang H, Mishima T (2008) Latest Olduvai short-lived reversal episodes recorded in Chinese loess. J Geophys Res: Solid Earth (1978-2012) 113:B5. doi:10.1029/2007JB005264

Yang T, Hyodo M, Yang Z, Li H, Maeda M (2010) Multiple rapid polarity swings during the Matuyama-Brunhes transition from two high-resolution loesspaleosol records. J Geophys Res 115:B05101. doi:10.1029/2009JB006301

Yang T, Li H, Wu H, Yang Z, Zhang S, Hyodo M (2012) Reliability of relative paleointensity recorded in Chinese loess-paleosol sediments. Acta Geologica Sinica (English Edition) 86(5):1276-88. doi:10.1111/j.1755-6724.2012.00747.x

Yang T, Hyodo M, Yang Z, Zhang S, Mishima T, Wu H, Li H, Li Y, Shi X, Wang K, Ma Y (2014) High-frequency polarity swings during the Gauss-Matuyama reversal from Baoji loess sediment. Sci China Earth Sci 57(8):1929-43. doi:10.1007/s11430-014-4825-4

Yue LP (1989) Magnetostratigraphical study of the loess section at Duanjiapo, Lantian, Shaanxi. Geol Rev 35:479-88 (in Chinese with an English abstract)

Yue LP (1995) Palaeomagnetic polarity boundary were recorded in Chinese loess and red clay, and geological significance. Acta Geophys Sinica 38:311-20 (in Chinese with an English abstract)
Zhang YP, Huang WP, Tang YJ, Ji HX, You YZ, Tong YS, Ding SY, Huang XS, Zhang JJ (1978) Cenozoic of Lantian Area, Shaanxi Mem Inst Vert Palaeontol and Palaeoanthropol, Academia Sinica A 14. Science Press, Beijing, in Chinese

Zhao X, Roberts AP (2010) How do Chinese loess become magnetized? Earth Planet Sci Lett 292:112-22. doi:10.1016/j.epsl.2010.01.026

Zhao H, Qiang X, Sun Y (2014) Apparent timing and duration of the MatuyamaBrunhes geomagnetic reversal in Chinese loess. Geochem Geophys Geosyst 15:4468-80. doi:10.1002/2014GC005497

Zheng H, An Z, Shaw J (1992) New contributions to Chinese Plio-Pleistocene magnetostratigraphy. Phys Earth Planet Inter 70:146-53. doi:10.1016/00319201(92)90177-W

Zhou LP, Shackleton NJ (1999) Misleading positions of geomagnetic reversal boundaries in Eurasian loess and implications for correlation between continental and marine sedimentary sequences. Earth Planet Sci Lett 168:117-30. doi:10.1016/S0012-821X(99)00052-7

Zhou W, Beck JW, Kong X, An Z, Qiang X, Wu Z, Xian F, Ao H (2014) Timing of the Brunhes-Matuyama magnetic polarity reversal in Chinese loess using ${ }^{10}$ Be. Geology 42:467-70. doi:10.1130/G35443.1

Zhu R, Laj C, Mazaud A (1994) The Matuyama-Brunhes and upper Jaramillo transitions recorded in a loess section at Weinan, north-central China. Earth Planet Sci Lett 125:143-58. doi:10.1016/0012-821X(94)90212-7

Zhu R, Coe RS, Guo B, Anderson R, Zhao X (1998) Inconsistent palaeomagnetic recording of the Blake event in Chinese loess related to sedimentary environment. Geophys J Int 134(3):867-75. doi:10.1046/j.1365246x.1998.00599.x

Zhu R, Pan Y, Liu Q (1999) Geomagnetic excursions recorded in Chinese loess in the last 70,000 years. Geophys Res Lett 26(4):505-8. doi:10.1029/ 1999GL900019

Zhu R, Liu Q, Jackson MJ (2004) Paleoenvironmental significance of the magnetic fabrics in Chinese loess-paleosols since the last interglacial (<130 ka). Earth Planet Sci Lett 221:55-69. doi:10.1016/S0012-821X(04)00103-7

Zhu R, Liu Q, Pan Y, Deng C, Sun J (2006) Identifying the origin of the magnetic directional anomalies recorded in the Datong loess profile, northeastern Chinese loess plateau. Geophys J Int 164:312-8. doi:10.1111/j.1365246X.2006.02848.X

Zhu ZY, Dennell R, Huang WW, Wu Y, Rao ZG, Xie JB, Liu W, Fu SQ, Han JW, Zhou HY, TP O y, Li HM (2015) New dating of the Homo erectus cranium from Lantian (Gongwangling), China. J Hum Evol 78:144-57. doi:10.1016/ j.jhevol.2014.10.001

\section{Submit your manuscript to a SpringerOpen ${ }^{\odot}$ journal and benefit from:}

- Convenient online submission

$\checkmark$ Rigorous peer review

- Immediate publication on acceptance

- Open access: articles freely available online

- High visibility within the field

- Retaining the copyright to your article

Submit your next manuscript at $>$ springeropen.com 